\title{
Academic inventions outside the university: Investigating patent ownership in the $\mathrm{UK}^{*}$
}

\author{
Cornelia Lawson ${ }^{\dagger \ddagger}$ \\ PUBLISHED IN SPECIAL ISSUE OF INDUSTRY AND INNOVATION \\ "INTELLECTUAL PROPERTY IN EUROPEAN UNIVERSITIES AND PUBLIC RESEARCH \\ ORGANIZATIONS"
}

\begin{abstract}
Please cite as: Lawson C. (2013) Academic inventions outside the university: Investigating patent ownership in the UK, Industry and Innovation, 20 (5), 385-398
\end{abstract}

\begin{abstract}
This paper investigates the ownership of academic patents for a sample of UK academics and challenges the existing definition of the university invention ownership model. The first descriptive results show that $50 \%$ of patents are owned by industry, however, $37 \%$ of these firm-assigned patents are in fact owned by university spin-offs. We investigate how university policy and funding acquisition impacts industry vs. university ownership, and find that funding from large firms predicts involvement in patenting and, to a lesser extent, firm ownership. University ownership of academic patents is more likely the higher the amount of funding coming from SMEs, and at universities that outsource the filing of patents. Spin-off patents occupy an intermediate position showing strong similarities to both firm and university patents.
\end{abstract}

Keywords: Academic patenting; University-industry collaboration; Sponsored research; Academic entrepreneurship; Patent ownership

JEL codes: I23; 031; 034

\footnotetext{
* The author would like to thank Aldo Geuna, three anonymous referees, and seminar participants at APE-INV Leuven, APIC Seoul, and MBIR, Manchester for helpful suggestions and comments. This paper contributes to the FP7 Project SISOB (\#266588) and the Collegio Carlo Alberto Project "Researcher Mobility and Scientific Performance". Sponsorship within the ESF Activity 'Academic Patenting in Europe' is also gratefully acknowledged.

$\dagger$ BRICK, Collegio Carlo Alberto, Via Real Collegio 30, 10024 Moncalieri (Turin), Italy

¥Department of Economics and Statistics "Cognetti de Martiis", University of Turin, Lungo Dora Siena 100A,

10153 Turin, Italy; cornelia.meissner@unito.it
} 


\section{Introduction}

The appropriation of academic intellectual property (IP) has been encouraged by policy makers over the past 30 years to foster technology transfer from universities to industry and to enable the commercialisation of academic research. One objective behind the increased incentives is the prospective additional income it may provide to universities. Another benefit is its potential to increase the efficiency of technology transfer by allowing non-exclusive licenses, by enabling wider use of an invention and by allowing for a better search strategy that ensures the commercialisation of the invention and thus providing wider socio-economic benefits (see Crespi et al. (2010) for a review). ${ }^{1}$

However, previous work has shown that in Europe a large proportion of inventions patented by academic researchers are not owned by the university but by private firms (Geuna and Nesta, 2006; Lissoni et al., 2008). Researchers and funding partners are able to claim rights over inventions due to existing appropriation norms and due to universities' difficulties in handling IP rights (IPR) (Geuna and Rossi, 2011). Changes in legislation and the continuing efforts of universities have led to a more rigid IPR regime for academic staff, but even now the majority of university inventions are not assigned to the academic institution. Patents left with the university are often those in need of more investment and little to no immediate returns (Thursby et al., 2009; Czarnitzki et al., 2012; Sterzi, 2013).

To date there have been few studies that attempt to explain the ownership of academic patents, other than those based on characteristics of the invention or national policy. Though it has been hypothesised that firms sponsoring academic research may seek ownership of any resulting inventions, these links have not as yet been investigated. Further, the large body of

\footnotetext{
${ }^{1}$ Kenney and Patton (2009) question the efficiency of this university ownership model that has made universities to "revenue maximizers, rather than facilitators of technology dissemination for the good of the entire society" (p. 1407).
} 
literature on academic spin-offs has not been incorporated into the discussion on ownership of academic patents. Markman et al. (2008) show that in the US firm ownership is more common in universities with a large number of academic spin-offs; firm ownership may thus suggest a different type of university ownership model that includes patents assigned to university spin-offs rather than a non-university ownership model as is commonly argued. Using data from a sample of engineering academics at thirteen UK universities this paper therefore aims to investigate the effect of industry involvement and university spin-off policy on the ownership of academic patents considering an academic's selection into patenting.

\section{Academic Patenting and Ownership}

\subsection{University versus Industry Ownership}

Starting with the Bayh-Dole act in the US, several countries have moved to actively pursue the protection of IP arising from university research. For many years it was believed that universities in Europe were lagging behind, as the number of university owned patents in Europe is much lower than in the US. However, recent research on university patenting in Europe has revealed a much larger involvement in patenting that does not follow the US model of university ownership but had flourished under non-university ownership models, e.g. professor's privilege (Geuna and Nesta, 2006). Lissoni et al. (2008) find that in some countries in Europe only $4 \%$ of academic patents are assigned to universities while up to $80 \%$ of academic inventions are owned by firms. Even for the US, Thursby et al. (2009) and Markman et al. (2008) report that approximately one third of patents are not owned by universities. These shares are lower than those found for Europe, but highlight the existence of different ownership models even in the US.

The UK occupies a position between the US and the rest of Europe in terms of patent ownership. Traditionally universities have been involved in the management of IP. In 1948 
the National Research Development Agency (later British Technology Group) was formed to commercialise inventions resulting from publicly funded research and the 1977 Patent Act specifically states that employee inventions belong to the employer (the university) which resulted in a move towards a university ownership model. Accordingly, the share of university owned inventions is much higher than compared to the rest of Europe ( $40 \%$ share) however, industry ownership remains at 50\% (Sterzi, 2013).

Thus the question remains as to what drives industry ownership in countries with an established university ownership model. One explanation that has been brought forward is that of firm-sponsored academic research. The university and the sponsoring firm may agree that any IP resulting from joint research projects are assigned to both the university and the firm or solely to the firm (Verspagen, 2006). Knowledge of such collaboration agreements is limited and there has been little empirical evidence confirming the link between sponsorship and patent ownership. Several papers have shown that collaboration with industry and other applied sponsors may help overcome the barrier between scientific and commercial activities and that contact with pro-commercialisation sponsors positively affects a researcher's attitude towards patenting as well as her ability to recognise commercial opportunities (Owen-Smith and Powell, 2001; Stuart and Ding, 2006). Further, Colyvas and Powell (2006), looking at technology transfer activities at Stanford University, observe that technology transfer offices (TTOs) and researchers see industry sponsors as potential partners for patenting activities. Indeed, in a survey by Lee (2000) both firms and academics report that joint research led to patentable outcomes or benefits in developing new patents. Accordingly, Hottenrott and Thorwarth (2011) in a survey of German professors investigate the potential effect of industry sponsorship on patenting and find a positive correlation. Lawson (2013), using a 12 year panel of academics from ten universities in the UK, also find a positive effect of industry funding on patenting regardless of ownership. This indicates that firm sponsorship 
encourages patenting in general but not a specific ownership model. The paper, however, does not consider selection into patenting and may therefore not find a differential effect on the two ownership regimes.

Additionally we could expect a different effect for funding coming from small as opposed to large firms. Firm innovation literature has shown that large firms are more likely to benefit from joint research with universities (Cohen et al., 2002; Mohnen and Hoareau, 2003). The same may be true for academics working with these large firms. We may further expect a different effect for ownership as large firms may be better placed to bargain over ownership rights than small firms. Hottenrott and Lawson (2013) differ between contacts to small and medium sized firms (SMEs) as opposed to large firms and find that contact with SMEs better explains patenting rates of German professors. This may be indicative of better support for the university ownership model from SMEs.

\subsection{Spin-off Ownership}

Several papers have investigated university spin-off formation and its role for technology transfer (e.g. Di Gregorio and Shane, 2003; Stuart and Ding, 2006; Clarysse et al., 2011; Fini et al., 2011). It has been shown that many university inventions result in spin-offs in which the university holds equity. This new company facilitates the commercialisation of the new invention and enables the acquisition of additional funding for commercialisation. Inventions that result in such spin-offs have been described as less basic (Thursby et al., 2009), and may thus be more likely to create immediate financial returns.

The university ownership model could therefore be further extended to include patents owned by university spin-offs. While firms that constitute university spin-offs are relatively easy to identify, only Thursby et al. (2009) have provided some statistics on the extent of academic patents owned by spin-offs. They report that $32 \%$ of all industry owned patents in the US are 
owned by companies associated to academics and that these are of higher quality than academic patents owned by industry or private firms. Also Markman et al. (2008) find some evidence that researchers at universities with a higher number of spin-off companies are more likely to file a patent that is owned by a firm or an individual. They assume, however, that such spin-offs are initiated by the academics, concluding that it presents a way to bypass university administration.

Instead, these spin-off companies could represent a deliberate commercialisation strategy of the university. Particularly in the UK, spin-off formation has been a preferred commercialisation strategy for universities. ${ }^{2}$ We can therefore expect that universities with an entrepreneurial strategy, i.e. with a larger number of spin-offs, are more likely to follow this alternative university ownership model and seemingly file more patents with industry.

To summarise, we add to existing studies by looking at a different definition of the university ownership model that allows for university and spin-off owned patents. We investigate how university policy and funding acquisition of academics impacts industry vs. university ownership to test the hypothesis that industry-funded research is more likely to result in industry owned patents. Finally, the UK as a country with a long history of university ownership directives but different IP strategies and/or insufficient enforcement provides a good example of a case study on drivers of patent ownership. ${ }^{3}$

\footnotetext{
2 Though US universities are more successful in licensing, UK universities create relatively more spin-off companies (HEFCE, 2011).

${ }^{3}$ Universities follow different strategies in managing IP. Some offices may only patent the most promising inventions (Meyer and Tang, 2007), while others may prefer to invest in spin-offs or choose not to enforce their rights (Markman et al., 2008).
} 


\section{Data and Methods}

\subsection{Data}

We create a novel dataset of tenured engineering academics who were employed at thirteen UK universities ${ }^{4}$ during the period 2001-2008. Initially, all engineering academics were identified using staff registers in academic calendars and on university websites. ${ }^{5}$ The population contains 744 academics. For each academic in the dataset, patent applications stating her as an inventor were collected from esp@ cenet (the European Patent Office (EPO) web-interface). The web-interface allows searches for patent applications filed with the EPO, the UK Intellectual Property Office (UKIPO), the US patent office (USPTO) and other national patent offices. We consider here all patent applications that state the researcher as an inventor and hence not only applications filed by the university but also those assigned to third parties, including industry. Data construction required a manual search in the inventor database to identify those entries where the identity of the academic was certain. ${ }^{6}$ As each invention can lead to multiple patent applications (e.g. at different patent offices), we additionally verified each entry with the Derwent World Patents Index (DWPI) that contains information grouped around a patent family, enabling us to uniquely identify the original invention and avoid multiple counts. In the remainder of the paper the term patent will refer to patent families grouped around an original priority patent (as defined in DWPI) and not to individual patents or patent applications. We collected patents filed between 1998 and 2008 and use the first three years (1998-2000) to build pre-observation measures of patent counts

\footnotetext{
${ }^{4}$ For a list of universities see Supplement S1.

${ }^{5}$ For a detailed description of the original data see Banal-Estanol et al. (2010). See Lawson (2013) for an analysis of sample distribution differences between the original data and a sub-sample of researchers at $10 \mathrm{UK}$ universities, which partially overlaps with the data used in this paper.

${ }^{6}$ The full process of extracting and cleaning the data is described in Meissner (2011).
} 
for our empirical models ${ }^{7}$ (see section 3.2). All descriptive statistics in this data section are based on the sample period 2001-2008 during which all 744 academics were employed at one of the thirteen institutions considered in this analysis. Of the 744 researchers, 176 file at least one patent during the period 2001-2008 (corresponding to 23\%) and the total number of patents is 456 . We identified the applicant on each patent. If a patent family has more than one patent we consider the assignees of the original (first) application. ${ }^{8}$ We differ between patents assigned to a university, a firm, the government or an individual. In this sample, 219 patents (48\%) are owned by universities and 226 patents (50\%) are assigned to private firms, shares equivalent to the ones found in Sterzi (2013). We collected information for each of the firm assignees from FAME$^{9}$. We then identified those companies that were spun out from universities. This was done by consulting the FAME company reports and company webpages as well as browsing the websites of universities for lists of spin-offs. Patents are owned by 114 different companies of which 54 are large firms with more than 249 employees and 31 are university spin-off companies. The remaining 29 firms are SMEs. More interestingly, while only about $27 \%$ of all firm applicants are university spin-offs, they account for $37 \%$ of all firm-assigned patents (83 patents). This share is similar to the one found by Thursby et al. (2009) for US patents. Large firms account for another 47\% (106 patents). This is in line with previous literature that showed that large firms and start-ups are more likely to engage in and benefit from collaborations with universities (Cohen et al., 2002; Mohnen and Hoareau, 2003).

\footnotetext{
${ }^{7}$ We do not have information on workplaces for all academics during the period 1998-2000 and therefore cannot make inferences on whether patents are academic patents or not.

${ }^{8}$ Ownership can change across time and across patent offices. In the case of regional sister patents, ownership can differ from that of the original application. This is ignored, as this extension happened at a later date. Even if we consider ownership on all sister patents across time only 15 patents are 'co-assigned' to different types of agents. This low number is partly due to the short time window with most applications not having entered regional stages at the time of data collection.

${ }^{9}$ FAME is a company information register for the UK.
} 
To complement the database we collect funding histories of academics. Funding information for the period 2001-2007 for each academic was provided by the research offices of the thirteen universities. They include names of principal investigators (PIs), funding periods, funding amounts and the exact names of sponsoring agents. Funding from industry accounts for $20 \%$ of total external funding and 453 researchers are PIs on at least one grant during the period 2001-2007. The other $80 \%$ of research grants come from public sources, including research councils and EU. 278 researchers received at least one grant from industry; in total 984 grants came from 402 different companies. This confirms that industry links through research funding partnerships are far more widespread than industry links through patents (Agrawal and Henderson, 2002; Cohen et al., 2002). The firms were identified on FAME and classified as SMEs or large firms (>249 employees). ${ }^{10}$ In our sample 212 sponsoring firms are SMEs and contribute 326 grants; 190 firms are large firms with 645 grants. We observe funding from 2001 to 2007 and expect the stock in previous years to reflect a researcher's current research profile and thus patents. In other words, we use the stock of funding between 2001 and $t-1$ to predict the ownership of patents filed in $t$. The total amount of funding received from SMEs (sme_funding), large firms (largefirm_funding) and public sponsors (public_funding) are considered.

To measure the appropriation strategy of the university, we use information from the Higher Education and Business and Community Interaction (HE-BCI) Survey that since 2003 has surveyed universities about their external business related activities. The survey provides detailed information about spin-off and patenting activities at the university level. Markman et al. (2008) found that spin-off numbers correlate positively with industry ownership. We therefore include the number of active spin-offs in $t-1$ that have survived for at least three

\footnotetext{
${ }^{10}$ We identified university spin-offs but they were only responsible for 20 grants during the observation period.
} 
years (\#spinoff) as a proxy for universities' spin-off policy. Due to the skewed nature of the measure we take its log in the regressions. Universities in our sample have between zero and 46 active spin-offs in 2007/08 (see Supplement S1). Markman et al. (2008) further observed that a for-profit TTO correlates positively with university ownership. Thus, the university's organisation of IP activities may affect ownership. We include a dummy that measures whether the university outsources filing of its patents (patent_outsourcing), as a measure for IP policy at the university level. ${ }^{11}$ The measure is constant throughout the observation period and eight universities outsource their IP activities (see Supplement S1).

Several additional measures have been shown to affect the researcher's propensity to engage in patenting. Amongst these we consider age at the time of invention as measured in terms of years since $\mathrm{PhD}$, its quadratic term, whether a researcher is female, seniority of the researcher (being a professor (prof)) and $\mathrm{PhD}$ subject area (chemical (chem), electrical and electronic (elec), and mechanical and civil engineering (mech_civ)), all of which have been identified as important predictors for academic productivity, including patenting (e.g. Stephan et al., 2007). They are therefore included in a first stage regression, determining a researcher's selection into patenting. Personal information could be collected for 687 academics. ${ }^{12}$

Previous literature has further shown a positive correlation between publications in scientific journals and patenting (e.g. Azoulay et al., 2007; Stephan et al., 2007; Fabrizio and DiMinin, 2008). We therefore also include a publication measure into the selection equation. Research activity measured as the average number of publications (avg_publications) published between 2001 and $t-1$ should capture the researcher's capability to produce innovative

\footnotetext{
${ }^{11}$ Other measures are not available or do not differ across institutions. For example, several papers have found that revenue incentives paid by universities increase disclosure activity of academic staff (Jensen and Thursby, 2001; Lach and Schankerman, 2008). However, revenue shares in the UK typically follow a structured system with lower returns for higher licensing amounts and are similar across universities. Therefore, we do not include them into the regression. Also, Markman et al. (2008) find no significant effect of licensing shares on university ownership when including other university characteristics.

${ }^{12}$ Information was taken from personal websites or Index to Theses, a listing of theses accepted for higher degrees in the UK and Ireland.
} 
research. It should however not impact ownership as for example Thursby et al. (2009) do not find a significant effect of department quality on patent ownership. Publications were collected from the Web of Science for the years 2001-2007 and cleaned manually.

Previous papers on ownership have primarily used patent characteristics like number of claims or citation counts as explanatory variables (Markman et al, 2008; Thursby et al., 2009); however, these are affected by ownership and by the norms of the respective patent office and are therefore not considered here. ${ }^{13}$

Table 1: Descriptive statistics

\begin{tabular}{|c|c|c|c|c|}
\hline & \multicolumn{2}{|c|}{ Selection Model (3278) } & \multicolumn{2}{|c|}{ Uncensored Model (267) } \\
\hline & Mean & $\mathrm{Sd}$ & Mean & $\mathrm{Sd}$ \\
\hline \multicolumn{5}{|l|}{ Dependent Variables } \\
\hline Patent $_{i t}$ & 0.08 & 0.27 & 1 & 1 \\
\hline University $_{i t}$ & & & 0.45 & 0.50 \\
\hline Firmit & & & 0.51 & 0.50 \\
\hline Non-spin-off it & & & 0.31 & 0.46 \\
\hline Spin-off it & & & 0.20 & 0.40 \\
\hline University/Spin-offit & & & 0.65 & 0.48 \\
\hline \multicolumn{5}{|c|}{ Institutional characteristics } \\
\hline ln_\#spinoffit-1 & 2.29 & 1.03 & 2.72 & 0.88 \\
\hline patent_outsourcing ${ }_{i}$ & 0.37 & 0.48 & 0.26 & 0.44 \\
\hline \multicolumn{5}{|l|}{ Funding (in $£ 100.000$ ) } \\
\hline sme_funding ${ }_{i t-1}$ & 0.20 & 1.15 & 0.59 & 2.29 \\
\hline largefirm_funding ${ }_{i t-1}$ & 0.62 & 3.36 & 2.58 & 7.85 \\
\hline public_funding $g_{i t-1}$ & 3.42 & 10.14 & 6.77 & 14.60 \\
\hline \multicolumn{5}{|l|}{ Other Variables } \\
\hline$l_{n \_}$prepat $_{i}$ & 0.08 & 0.35 & 0.54 & 0.81 \\
\hline$d_{\text {_pprepat }}$ & 0.87 & 0.34 & 0.51 & 0.50 \\
\hline age $_{i t}$ & 20.45 & 10.96 & 20.48 & 9.46 \\
\hline \multicolumn{5}{|l|}{ Selection Variables } \\
\hline avg_publication $i t-1$ & 1.72 & 2.46 & 3.75 & 4.33 \\
\hline female $_{i}$ & 0.07 & 0.26 & 0.05 & 0.21 \\
\hline prof $_{i t}$ & 0.40 & 0.49 & 0.58 & 0.48 \\
\hline elec $_{i}$ & 0.38 & 0.48 & 0.62 & 0.48 \\
\hline mech_civi & 0.32 & 0.47 & 0.11 & 0.32 \\
\hline
\end{tabular}

\footnotetext{
${ }^{13}$ Most patents in our data are still being examined and have not as yet entered regional phase (in case of Patent Cooperation Treaty patents), which further makes the use of patent-based measures problematic. Only 44 patents had been granted when the data was collected in 2012, either at the EPO (14) or at a regional office and only 2 EPO patents had received any citations.
} 
Table 1 presents descriptive statistics for the full sample and for the reduced sample of patent events. Supplement S1 contains some additional information on the composition of the sample by university. A full definition of all variables and correlation tables for the main variables can be found in Supplements S2 and S3, respectively.

Only patents filed between 2004 and 2008 are considered in the regressions to be able to build reliable measures of all explanatory variables. The number of patents is reduced to $267^{14}$ due to missing values in some of the estimators and a reduced observation period. $45 \%$ of these patents are owned by the university, $20 \%$ by university spin-offs and $31 \%$ by firms. $3 \%$ are in co-ownership between universities and private firms. The remaining $7 \%$ are owned by individuals or government.

\subsection{Empirical Strategy}

Our main interest is patent ownership, which can be the university, a university spin-off, a firm, or a combination thereof. ${ }^{15}$ The empirical set-up investigates if a patent by an academic researcher is filed with a firm or the university as opposed to other types of ownership. The definition of firm and university is challenged here as university spin-offs could be considered either.

As a researcher has the choice between two or more outcomes, their standard errors are not independent and require us to estimate them simultaneously, making it necessary to consider a bivariate model as opposed to a binary choice model. The bivariate probit estimator may be biased by self-selection into patenting. For example, researchers who receive less funding may also be less likely to patent. This would lead to an upward bias of the effect of funding

\footnotetext{
${ }^{14}$ In fact we are looking at 244 patents; 23 patents have more than one inventor in the dataset. We consider these multiple counts of the same patent as explanatory variables differ across researchers.

${ }^{15}$ Ownership can lie with the government or solely with an individual but these account for just 23 observations and are not included as separate categories.
} 
on patent ownership. To address this bias we include bivariate probit models that account for selection into patenting (see Supplement S4 for details). In these models the inventor's academic publications, seniority, subject area and gender serve as exclusion restrictions as these variables have been found to be important predictors for patenting in previous research (e.g. Stephan et al., 2007). However, we do not expect them to influence the choice of a specific ownership form. The exclusion restrictions are supported as none of these variables significantly influence ownership if included in the second stage. The model is estimated with Maximum Simulated Likelihood Method using the GHK simulator (Gates, 2006). ${ }^{16}$

Our estimation could further be biased by unobserved effects, e.g. specific skills that are necessary to source funding. If unobserved individual-specific heterogeneity is present, the estimated coefficient of the funding variables would be upwards biased. To control for such unobserved heterogeneity we follow Blundell et al. (2002), who suggest a solution which they call "feedback model". The feedback model argues that the main source of unobserved heterogeneity lies in the different values of the dependent variable with which individuals enter the sample. This approach also helps to address the problem of endogeneity that arises from correlated individual effects and through feedback from the dependent variable. We therefore include a log of the pre-sample value, given by the number of patents filed between 1998 and 2000, into the pooled models. For cases when the pre-sample value is zero a dummy is used to capture the "quasi-missing" value in log.

While we have a panel set-up, some individuals may have more than one observation per year if they filed more than one patent. We include year fixed effects and cluster standard errors at the individual level to mitigate this bias. We include several robustness checks to confirm the

\footnotetext{
${ }^{16}$ We use the user-written command $\mathrm{cmp}$ in Stata to estimate the bivariate probit models with selection (Roodman, 2009).
} 
consistency of our estimates, including, amongst others, a multinomial logit allowing for three ownership outcomes.

\section{Results}

Results are reported in Table 2. Columns 1 report the results of the first stage selection into patenting and columns 2 and 3 the second stage models for industry and university ownership. The Likelihood-Ratio tests of independent equations are rejected thus supporting our model choice.

The second stage regression shows that the number of university spin-offs has no effect on patent ownership. However, it affects the selection into patenting indicating that researchers at universities with more spin-offs are more likely to patent. Conversely, outsourcing of IP protection has no effect on patenting propensity but a positive effect on university ownership. Concerning funding from industry, we find that funding coming from SMEs has a positive effect on university ownership but a negative effect on firm ownership of patents, while funding from large firms has the opposite effect. If in addition we consider the results from the selection model, we see that only sponsorship from large firms affects the overall propensity to patent, while funding from small firms has no effect. Public grants, on the other hand, are more likely to result in university owned patents while decreasing the overall propensity to patent.

Past patenting experience is positively associated with the selection into patenting and with firm-ownership, but negatively with university ownership. Age only affects selection into patenting. Regarding the exclusion restrictions we find that publication intensity and seniority affect selection into patenting, while gender has no effect. Researchers in mechanical and civil engineering are less likely to select into patenting than their colleagues in electronics and chemical engineering (the omitted category). 
S5 shows that the results hold when conflating multiple person-year observations into one observation, thus allowing for more overlap amongst the patent ownership variables. The most important differences we observe is that public grants no longer affect university ownership significantly and that funding from large firms turns insignificant in the firmownership equation. Results also largely hold if we exclude patents with multiple or other types of owners and estimate a univariate probit of university ownership with selection correction, but again only SME funding remains significant.

As argued above, spin-off firms cannot be strictly considered firms but are often (partially) owned by the university, which profits from successful spin-off activity. We therefore investigate an alternative definition of university patents that includes patents of university spin-offs. The results in columns 4 to 6 of Table 2 show that coefficients of funding from large firms increase, indicating that the industry funding behind spin-off patents is more similar to that of university owned patents. However, the coefficients for public funding, SME funding and institutional variables decrease indicating that spin-off patents inhibit some characteristics that differ from other university patents. This is confirmed in the robustness regression in Supplement S5.

As a last step we therefore look at the three types of patents in a multinomial logit, excluding all observations with zero patents and patents that are assigned to multiple owners or owned by none of the three categories, which reduces the number of observations to $237 .{ }^{17}$ The suest-based Hausman test shows that the null hypothesis of independent alternatives cannot be rejected and thus confirms that disturbances in the three categories are independent. To complement these results, we perform Likelihood-Ratio tests of combing alternatives in order to determine whether certain categories can be collapsed. This is rejected for all pairs of

\footnotetext{
${ }^{17}$ A multivariate probit with selection was not possible as the model would not converge. As an alternative one could perform separate probit estimations and indeed the results are confirmed. The descriptive statistics for the reduced number of observations can be found in Supplement S5.
} 
outcome categories. Again, we cluster standard errors on the individual inventor. The results show that spin-off patents do not differ from either of the other two categories significantly in any of our main variables of interest, with the exception of IP outsourcing. Thus, while we have been able to identify some differences between firm and university owned patents primarily with regard to sponsorship from SMEs, university spin-offs seem to share characteristics of both. This is further illustrated in Figure 1.

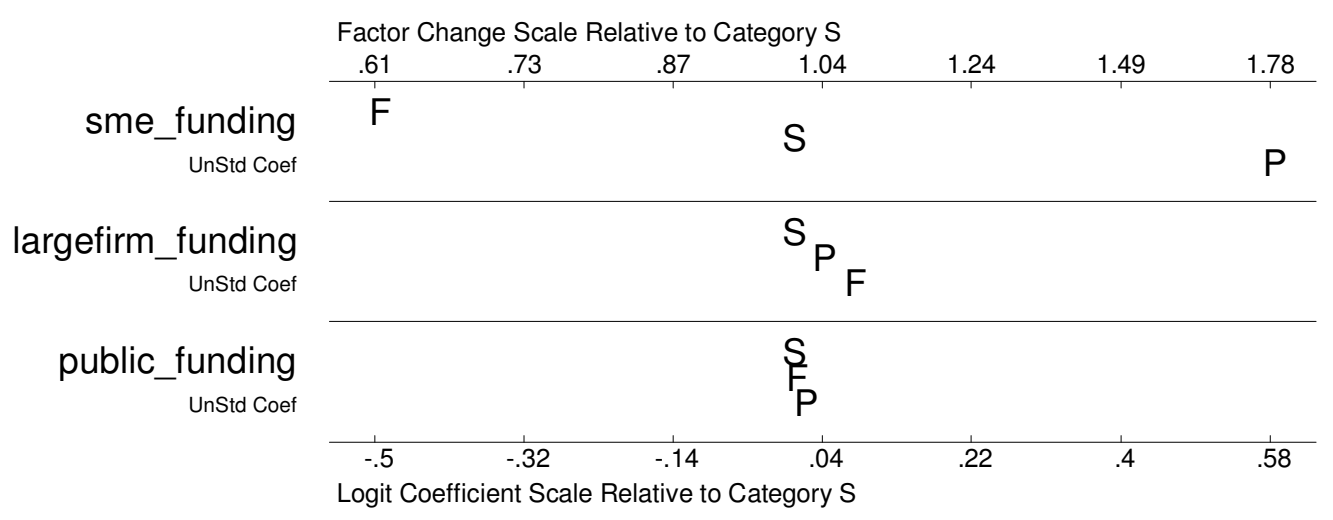

Figure 1: Odds ratios and discrete changes relative to university spin-off (S) (Long and Freese, 2005)* $* \mathrm{~F}=$ non-spin-off firm patent; $\mathrm{S}=$ spin-off patent; $\mathrm{P}=$ =university patent

In Supplement S5 we report results splitting public funding into funding received from research councils and charities on the one side and funding from government and the European Union (EU) on the other side to investigate if different types of public funding have different effects on ownership. The results show that the positive effect of public funding on university ownership is driven by research council and charity grants. In the multinomial logit we can further see that researchers receiving larger amounts of government and EU grants are more likely to file spin-off patents as compared to both the other two categories. Further the industry funding variables turn significant, indicating that the more funding researchers receive from large firms the more likely the patent will be assigned to an established firm rather than to a university spin-off, and the more funding is received from SMEs the more likely the patent will be assigned to the university rather than a spin-off or an established firm. 
Table 2: Bivariate Probit with Selection and Multinomial Logit

\begin{tabular}{|c|c|c|c|c|c|c|c|c|c|}
\hline \multirow[b]{2}{*}{ VARIABLES } & \multirow{2}{*}{$\begin{array}{c}\text { First stage } \\
\text { Patent }\end{array}$} & \multicolumn{2}{|c|}{ Second stage } & \multirow{2}{*}{$\begin{array}{c}\text { First stage } \\
\text { Patent }\end{array}$} & \multicolumn{2}{|c|}{ Second stage } & \multicolumn{3}{|c|}{ Multinomial logit } \\
\hline & & University & Firm & & University/spin-off & Non-spin-off firm & $\begin{array}{l}\text { SPIN/ } \\
\text { UNIV }\end{array}$ & $\begin{array}{l}\text { FIRM/ } \\
\text { UNIV }\end{array}$ & $\begin{array}{l}\text { FIRM/ } \\
\text { SPIN }\end{array}$ \\
\hline ln_\#spinoff ${ }_{i-1}$ & $\begin{array}{l}0.138^{* * *} \\
(0.055)\end{array}$ & $\begin{array}{l}-0.057 \\
(0.100)\end{array}$ & $\begin{array}{c}0.010 \\
(0.129)\end{array}$ & $\begin{array}{c}0.129 * * \\
(0.057)\end{array}$ & $\begin{array}{l}-0.023 \\
(0.120)\end{array}$ & $\begin{array}{l}0.000 \\
(0.119)\end{array}$ & $\begin{array}{l}-0.041 \\
(0.031)\end{array}$ & $\begin{array}{l}-0.031 \\
(0.026)\end{array}$ & $\begin{array}{c}0.011 \\
(0.033)\end{array}$ \\
\hline patent_outsourcing $_{i}$ & $\begin{array}{l}-0.068 \\
(0.128)\end{array}$ & $\begin{array}{l}0.419^{*} \\
(0.222)\end{array}$ & $\begin{array}{l}-0.435 \\
(0.267)\end{array}$ & $\begin{array}{l}-0.064 \\
(0.129)\end{array}$ & $\begin{array}{c}0.185 \\
(0.284)\end{array}$ & $\begin{array}{l}-0.176 \\
(0.300)\end{array}$ & $\begin{array}{l}-2.031^{*} \\
(1.044)\end{array}$ & $\begin{array}{l}-0.950 \\
(0.620)\end{array}$ & $\begin{array}{c}1.081 \\
(1.099)\end{array}$ \\
\hline sme_funding it-l $_{1}$ & $\begin{array}{l}-0.042 \\
(0.031)\end{array}$ & $\begin{array}{c}0.161 * * \\
(0.071)\end{array}$ & $\begin{array}{c}-0.214 * * * \\
(0.060)\end{array}$ & $\begin{array}{l}-0.039 \\
(0.031)\end{array}$ & $\begin{array}{l}0.142 * \\
(0.073)\end{array}$ & $\begin{array}{c}-0.198 * * * \\
(0.058)\end{array}$ & $\begin{array}{l}-0.575 \\
(0.353)\end{array}$ & $\begin{array}{c}-1.071 * * \\
(0.527)\end{array}$ & $\begin{array}{l}-0.496 \\
(0.579)\end{array}$ \\
\hline largefirm_funding $_{\text {it- }-1}$ & $\begin{array}{c}0.031 * * * \\
(0.010)\end{array}$ & $\begin{array}{c}-0.034 * * \\
(0.015)\end{array}$ & $\begin{array}{c}0.039 * * \\
(0.019)\end{array}$ & $\begin{array}{c}0.030 * * * \\
(0.010)\end{array}$ & $\begin{array}{c}-0.040 * * \\
(0.019)\end{array}$ & $\begin{array}{c}0.046^{* *} * \\
(0.022)\end{array}$ & $\begin{array}{l}-0.037 \\
(0.061)\end{array}$ & $\begin{array}{c}0.037 \\
(0.064)\end{array}$ & $\begin{array}{c}0.073 \\
(0.059)\end{array}$ \\
\hline public_funding $g_{i t-I}$ & $\begin{array}{l}-0.006^{*} \\
(0.003)\end{array}$ & $\begin{array}{l}0.008^{* *} \\
(0.004)\end{array}$ & $\begin{array}{c}-0.010 * * \\
(0.004)\end{array}$ & $\begin{array}{c}-0.005 \\
(0.003)\end{array}$ & $\begin{array}{l}0.008 \\
(0.006)\end{array}$ & $\begin{array}{l}-0.008 \\
(0.006)\end{array}$ & $\begin{array}{l}-0.015 \\
(0.011)\end{array}$ & $\begin{array}{c}-0.011 \\
(0.012)\end{array}$ & $\begin{array}{c}0.003 \\
(0.017)\end{array}$ \\
\hline ln_prepat ${ }_{i}$ & $\begin{array}{c}0.636 * * * \\
(0.152)\end{array}$ & $\begin{array}{c}-0.338^{*} \\
(0.190)\end{array}$ & $\begin{array}{c}0.470 * * \\
(0.183)\end{array}$ & $\begin{array}{c}0.616^{* * * *} \\
(0.155)\end{array}$ & $\begin{array}{l}-0.008 \\
(0.202)\end{array}$ & $\begin{array}{c}0.164 \\
(0.188)\end{array}$ & $\begin{array}{c}0.737 \\
(0.462)\end{array}$ & $\begin{array}{l}-0.246 \\
(0.412)\end{array}$ & $\begin{array}{r}-0.983 * * \\
(0.467)\end{array}$ \\
\hline$d_{\text {_prepat }}$ & $\begin{array}{c}-0.412^{* *} \\
(0.169)\end{array}$ & $\begin{array}{c}0.688^{* * * *} \\
(0.249)\end{array}$ & $\begin{array}{c}-0.706^{* *} \\
(0.275)\end{array}$ & $\begin{array}{c}-0.422^{* *} \\
(0.169)\end{array}$ & $\begin{array}{l}0.431^{*} \\
(0.239)\end{array}$ & $\begin{array}{l}-0.505^{*} \\
(0.258)\end{array}$ & $\begin{array}{l}-1.243^{*} \\
(0.754)\end{array}$ & $\begin{array}{c}-1.149^{*} \\
(0.587)\end{array}$ & $\begin{array}{c}0.094 \\
(0.737)\end{array}$ \\
\hline age $_{i t}$ & $\begin{array}{c}0.041 * * \\
(0.018)\end{array}$ & $\begin{array}{l}-0.057 \\
(0.038)\end{array}$ & $\begin{array}{c}0.024 \\
(0.035)\end{array}$ & $\begin{array}{c}0.037 * * \\
(0.018)\end{array}$ & $\begin{array}{l}-0.021 \\
(0.036)\end{array}$ & $\begin{array}{l}-0.024 \\
(0.035)\end{array}$ & $\begin{array}{c}0.109 \\
(0.113)\end{array}$ & $\begin{array}{l}-0.006 \\
(0.080)\end{array}$ & $\begin{array}{l}-0.115 \\
(0.119)\end{array}$ \\
\hline$a g e_{i t}^{2}$ & $\begin{array}{c}-0.001 * * * * \\
(0.000)\end{array}$ & $\begin{array}{l}0.001 * \\
(0.001)\end{array}$ & $\begin{array}{l}-0.001 \\
(0.001)\end{array}$ & $\begin{array}{c}-0.001 * * * \\
(0.000)\end{array}$ & $\begin{array}{c}0.001 \\
(0.001)\end{array}$ & $\begin{array}{c}0.000 \\
(0.001)\end{array}$ & $\begin{array}{l}-0.002 \\
(0.002)\end{array}$ & $\begin{array}{l}-0.000 \\
(0.002)\end{array}$ & $\begin{array}{c}0.002 \\
(0.003)\end{array}$ \\
\hline avg_publication $_{i t-1}$ & $\begin{array}{c}0.048 * * * \\
(0.017)\end{array}$ & & & $\begin{array}{c}0.048 * * * \\
(0.017)\end{array}$ & & & & & \\
\hline female $_{i}$ & $\begin{array}{l}-0.281 \\
(0.267)\end{array}$ & & & $\begin{array}{l}-0.320 \\
(0.274)\end{array}$ & & & & & \\
\hline $\operatorname{prof}_{i t}$ & $\begin{array}{c}0.289 * * \\
(0.123)\end{array}$ & & & $\begin{array}{l}0.251^{*} \\
(0.132)\end{array}$ & & & & & \\
\hline elec $_{i}$ & $\begin{array}{c}0.153 \\
(0.142)\end{array}$ & & & $\begin{array}{c}-0.356^{* *} \\
(0.159)\end{array}$ & & & & & \\
\hline mech_civ $v_{i}$ & $\begin{array}{c}-0.285^{*} \\
(0.159)\end{array}$ & & & $\begin{array}{c}0.166 \\
(0.151)\end{array}$ & & & & & \\
\hline constant & $\begin{array}{c}-1.934 * * * \\
(0.322) \\
\end{array}$ & $\begin{array}{l}1.306 * * \\
(0.550)\end{array}$ & $\begin{array}{c}-0.873 \\
(0.670)\end{array}$ & $\begin{array}{c}-1.868 * * * \\
(0.321) \\
\end{array}$ & $\begin{array}{l}1.081 * \\
(0.622)\end{array}$ & $\begin{array}{l}-0.720 \\
(0.671) \\
\end{array}$ & $\begin{array}{c}-0.483 \\
(1.773) \\
\end{array}$ & $\begin{array}{c}1.609 \\
(1.233)\end{array}$ & $\begin{array}{c}2.091 \\
(1.945) \\
\end{array}$ \\
\hline $\begin{array}{l}\text { athrho_Firm_Univ } \\
\text { athrho_Firm_Pat } \\
\text { athrho_Univ_Pat }\end{array}$ & & $\begin{array}{c}-2.097 * * * \\
0.804 * * \\
-0.978 * *\end{array}$ & & & $\begin{array}{c}-2.095 * * * \\
0.643 * * * \\
-0.676 * * *\end{array}$ & & & & \\
\hline Observations (uncensored) & & $3278(267)$ & & & $3278(267)$ & & & 237 & \\
\hline Wald-chi & & $82.376^{* * * *}$ & & & $21.682 *$ & & & $66.54 * * *$ & \\
\hline Log-Likelihood & & -955.963 & & & -947.337 & & & $\begin{array}{c}-217.820 \\
0130\end{array}$ & \\
\hline
\end{tabular}




\section{Conclusion}

This paper investigated the patent ownership of university invented patents. Prior research in the field has shown that academics in Europe are inventors on a large number of patents that are not assigned to the academic's institution but to a private firm or the academic herself (Geuna and Nesta, 2006). Previous papers have argued that this may be due to appropriation norms that have allowed researchers or funding agents to maintain the rights to their inventions or due to universities' difficulties in handling IPR. Changes in legislation and the continuing efforts of university administrations have led to a more rigid IPR regime for academic staff. However, even now the majority of university inventions are not assigned to the institution. For example, in the UK around $50 \%$ of university inventions are filed with a private firm and not the university (Sterzi, 2013).

Using data on engineering academics in the UK, this paper investigated the drivers behind university and firm ownership of university invented patents. It differed between patents assigned to university spin-offs and patents assigned to other private firms and used information on university appropriation strategies and industry funding to shed light on the factors that drive firm ownership of patents. The first descriptive results showed that $27 \%$ of firms that own university invented patents are university spin-offs and account for $37 \%$ of firm-assigned patents. Thus, a major share of academic patents owned by industry are in fact owned by university spin-offs. Spin-off formation may thus present an alternative appropriation strategy of the university.

Using bivariate probit models with selection correction we saw that funding from SMEs supports a university ownership model that includes university patents owned by the university and its spin-offs. Funding from large firms, on the other hand, supports an industry ownership model. This may indicate that universities are better able to enforce ownership 
rights resulting from joint research with SMEs but that this enforcement is more difficult in joint research with large firms. Public funding is closer aligned with university ownership that does not include spin-off ownership. Spin-off companies seem to occupy an intermediate position between strict university ownership and strict industry ownership. Indeed the multinomial logit analysis confirms that the predictors of spin-off owned patents do not differ significantly from either of the other two ownership regimes.

We further find that industry sponsorship and a strong spin-off strategy of the university encourage patenting. This indicates that contact with large firms and closeness to local startups can be indicative of future appropriation of research.

With regard to TTO management, one could argue that if university ownership is sought the bargaining position of researchers towards large firms needs to be strengthened. Universities that outsource their IP activities already seem more likely to keep their IP, perhaps due to a stronger bargaining position. On the other hand, large firms provide much greater funding than SMEs and universities may willingly forgo IP ownership in return for large research grants.

Finally, while the results allow making inferences about the effect of university IPR regimes and industry sponsorship on patent ownership, the results cannot be interpreted as direct links. Instead, they are indicative of a culture in which the appropriation of knowledge is promoted and rewarded. The paper also shows that more research is needed to better explain ownership regimes, and that more diverse processes may be at work when decisions regarding appropriation of university research are made. 


\section{Supplements}

S1 - Sample Composition

S2- Variable Description

S3 - Correlation Matrix

S4 - Methodological Note

S5 - Robustness Tests

\section{References}

Agrawal, A., Henderson, R., 2002. Putting patents in context: exploring knowledge transfer from MIT. Management Science 48, 44-60.

Azoulay, P., Ding, W., Stuart, T., 2007. The determinants of faculty patenting behavior: demographics or opportunities? Journal of Economic Behavior and Organization 63, $599-623$.

Banal-Estanol, A., Jofre-Bonet, M., Meissner, C., 2010. The impact of industry collaboration on research: Evidence from engineering academics in the UK. UPF Working Paper no1190. Barcelona, Spain.

Blundell, R., Griffith, R., Windmeijer, F., 2002. Individual Effects and Dynamics in Count Data Models. Journal of Econometrics 108, 113-131.

Clarysse, B., Tartari, V. Salter, A., 2011. The impact of entrepreneurial capacity, experience and organizational support on academic entrepreneurship. Research Policy 40, 10841093.

Cohen, W.M., Nelson, R.R., Walsh J., 2002. Links and impacts: the influence of public research on industrial R\&D. Management Science 48, 1-23.

Colyvas, J.A., Powell, W.W., 2006. Roads to institutionalization: the remaking of boundaries 
between public and private science. Research in Organizational Behavior 27, 305-353.

Crespi, G., Geuna, A., Nomaler, O., Verspagen, B., 2010. University IPRs and knowledge transfer: is university ownership more efficient? Economics of Innovation and New Technology 19, 627-648.

Czarnitzki, D., Hussinger, K., Schneider, C., 2012. The nexus between science and industry: evidence from faculty inventions. Journal of Technology Transfer 37, 755-776.

Di Gregorio, D., Shane, S., 2003. Why do some universities generate more start-ups than others? Research Policy 32, 209-227.

Fabrizio, K., DiMinin, A., 2008. Commercializing the Laboratory: Faculty Patenting and the Open Science Environment. Research Policy 37, 914-931.

Fini, R., Lacetera, N., Shane, S., 2011. Inside or outside the IP system? Business creation in academia. Research Policy 39, 1060-1069.

Gates, R. 2006. A Mata Geweke-Hajivassiliou-Keane multivariate normal simulator. Stata Journal 6, $190\{213$.

Geuna, A., Nesta, L., 2006. University patenting and its effects on academic research: The emerging European evidence. Research Policy 35, 790-807.

Geuna, A., Rossi, F., 2011. Changes to university IPR regulations in Europe and the impact on academic patenting. Research Policy 40, 1068-1076.

HEFCE (2011). Higher education - Business and community interaction survey 2009-2010. HEFCE, London.

Hottenrott, H., Thorwarth, S., 2011. Industry Funding of University Research and Scientific Productivity. Kyklos 64, 534-555.

Hottenrott, H., Lawson, C., 2013. Research Grants, Sources of Ideas and the Effects on Academic Research. Economics of Innovation and New Technology, forthcoming. 
Kenney, M., Patton, D., 2009. Reconsidering the Bayh-Dole Act and the current university invention ownership model. Research Policy 38, 1407-1422.

Jensen, R., Thursby, M., 2001. Proofs and prototypes for sale: The licensing of university inventions. American Economic Review 91, 240-259.

Lach, S., Schankerman, M., 2008. Incentives and invention in universities. The Rand Journal of Economics 39, 403-433.

Lawson, C., 2013. Academic patenting: The importance of industry support. Journal of Technology Transfer 38, 509-535.

Lee, Y.S. 2000. The sustainability of university-industry research collaboration: an empirical assessment. Journal of Technology Transfer 25, 111-133.

Lissoni, F., Llerena, P., McKelvey, M., Sanditov, B., 2008. Academic patenting in Europe: new evidence from the KEINS database. Research Evaluation 17, 87-102.

Long, S.J., Freese, J., 2005. Regression Models for Categorical Outcomes Using Stata. Second Edition. College Station, TX: Stata Press.

Markman, G.D., Gianiodis, P.T., Phan, P.H., 2008. Full-time faculty or part-time entrepreneurs. IEEE Transactions on Engineering Management 55, 29-36.

Meissner, C., 2011. University Research and Industry Involvement. PhD Thesis, City University, London.

Meyer, M., Tang, P., 2007. Exploring the 'value' of academic patents: IP management practices in UK universities and their implications for third-stream indicators. Scientometrics 70, 415-440.

Mohnen, P., Hoareau, C., 2003. What type of enterprise forges close links with universities and government labs? evidence from CIS 2. Managerial and Decision Economics 24, $133-146$.

Owen-Smith, J., Powell, W.W., 2001. To patent or not: Faculty Decisions and institutional 
success at technology transfer. Journal of Technology Transfer 26, 99-114.

Roodman, D. 2009. Estimating Fully Observed Recursive Mixed-Process Models with cmp, Center for Global Development, CGD Working Paper 168, Washington.

Stephan, P.E., Gurmu, S., Sumell, A.J., Black, G., 2007. Who's patenting in the university? Evidence from the survey of doctorate recipients. Economics of Innovation and New Technology 16, 71-99.

Sterzi, V., 2013. Patent quality and ownership: An analysis of UK faculty patenting. Research Policy 42, 564-576.

Stuart, T.E., Ding, W.W., 2006. When do scientists become entrepreneurs? The social structural antecedents of commercial activity in the academic life sciences. American Journal of Sociology 112, 97-144.

Thursby, J., Fuller, A.W., Thursby, M., 2009. US faculty patenting: Inside and outside the university. Research Policy 38, 14-25.

Verspagen, B., 2006. University research, intellectual property rights and European innovation systems. Journal of Economic Surveys 20, 633-690. 